DOI: $10.17951 / \operatorname{lrp} .2019 .38 .4 .111-123$

\author{
BARbARA BilewiCZ-KuŹNIA \\ Uniwersytet Marii Curie Skłodowskiej, Instytut Pedagogiki \\ ORCID - 0000-0003-1333-095X \\ Manuela Valentini \\ Dipartimento di Studi Umanistici \\ Università degli Studi di Urbino Carlo Bo \\ ORCID - 0000-0003-2655-1778
}

Angelica Nocciolino

\title{
EDUKACJA PRZEZ RUCH W PRAKTYCE BADAWCZEJ
}

\begin{abstract}
Streszczenie: Liczne studia interdyscyplinarne i międzynarodowe badania wykazują, że proces uczenia się może być projektowany z wykorzystaniem wiedzy o cielesności jednostki, poprzez edukację w ruchu oraz z wykorzystaniem ciała i przez to wspierać rozwój poznawczy, społeczny, emocjonalny i zdrowotny jednostki postrzeganej integralnie. Najwybitniejszym przedstawicielem pedagogiki ruchu był wychowawca, lekarz Jean Le Boulch, twórca psychomotorycznej teorii uczenia się. Zgodnie z nią nie można osiągnąć postępu intelektualnego bez pomocy ciała i umiejętności motorycznych. Artykuł stanowi przegląd badań naukowych dotyczących psychomotoryki edukacyjnej i jej licznych korzyści dla integralnego rozwoju dziecka. Podkreślono w nim, że harmonia między umysłem a ciałem promuje pozytywne procesy wzrostu jednostki.
\end{abstract}

Słowa kluczowe: psychomotoryka, aktywność ruchowa, wiek rozwojowy, pedagogika, integralność psychofizyczna

\section{WPROWADZENIE}

Psychomotoryczna teoria uczenia się, określana także w skrócie jako psychomotoryka, psychomotoryka funkcjonalna czy opisywana też jako edukacja przez ruch (Le Boulch 1966, 1981, 1989), zajmuje się holistycznym wpływem ciała i jego ruchu na rozwój i funkcjonowanie jednostki. Jej twórcami są Francuzi: Bernard 
Aucouturier (2005), Andrè Lapierre (2001) i Jean Le Boulch (1966, 1990), którzy dzięki swoim badaniom wpłynęli na rozwój tej dziedziny wiedzy (Coste, 2011). U podstaw psychomotoryki leży założenie, że ruch człowieka jest połączony z jego umysłem i jest ważnym czynnikiem rozwoju. Dzięki tej nauce aktywność ruchowa uznawana jest jako ważne narzędzie i czynnik wychowawczy oraz edukacyjny zarówno dla dzieci pełnosprawnych, jak i niepełnosprawnych. Przedmiotem badań psychomotoryki jest istota ludzka postrzegana całościowo. Dziedzina ta stara się łączyć cielesność, uczuciowość, inteligencję i społeczność, badając aktywność ruchową z psychologicznego punktu widzenia. Przedmiot jej zainteresowań możemy opisać jako rezultat wzajemnego dialogu między układem neurologicznym a narządem ruchu (Zanibelli 2013). W psychomotoryce zakłada się, że jeśli umysł potrzebuje informacji pochodzących $\mathrm{z}$ naszego ciała, aby zaplanować i wykonać ruch, to również ciało potrzebuje umysłu, aby wyrazić i zaplanować ruch. Z kolei ruch wpływa na takie zdolności umysłowe, jak uczucia, motywacja, koncentracja. Wychodząc z tej perspektywy, która sprzeciwia się dualizmowi umysł - ciało, według którego te dwa czynniki są niezależne od siebie, wydaje się oczywiste, że praktyka psychokinetyczna uznaje jednostkę w swojej integralności psychosomatycznej. Praktyka psychomotoryczna może być zarazem terapeutyczna, jak i edukacyjna. Ta pierwsza, zwana także „terapią mediacji ciała” (De Panfilis, Camerini 2005), jest stosowana, gdy zdolności psychomotoryczne są zagrożone przez choroby neurologiczne i w tych przypadkach instruktor psychomotoryki pracuje nad ekspresją ciała, co pozwala zrekompensować trudności danej osoby. Natomiast psychomotoryka edukacyjna, na której skoncentrował się Le Boulch, zostaje wykorzystana w edukacji (szkolnej i pozaszkolnej), ponieważ ma pozytywny wpływ na psychofizyczny rozwój dziecka. Edukacja psychokinetyczna pełni również funkcję profilaktyczną wobec niektórych problemów związanych z rozwojem, takich jak trudności w komunikacji interpersonalnej (Biagini 2008). Wiele prac badawczych potwierdza, że wykorzystanie wiedzy o rozwoju psychoruchowym człowieka w obszarze edukacyjnym jest fundamentalne. Zgodnie z nią dziecko wyraża siebie w sposób całościowy i spontaniczny, poprzez swoje ciało, które od urodzenia jest uprzywilejowanym kanałem służącym do poznania siebie samego i otaczający nas świat oraz do nawiązywania relacji z innymi. Dzięki zabawie i ruchowi małe dzieci potrafią zrozumieć wartość czasu i przestrzeni. Psychomotoryka może pomóc nie tylko w celu interakcji z własnym ciałem, ucząc jak nad nim zapanować, ale także $\mathrm{w}$ relacji z osobami, z którymi nawiązuje się kontakt, rozwijając lepszą koordynację. To zrewolucjonizowało podejście do edukacji, gdyż zwróciło uwagę na konieczność myślenia o dziecku jako o jednostkowej całości, potrzebującej całościowej edukacji (Wille, Ambrosini 2005). Globalność podejścia psychokinetycznego sprawia, że staje się ono idealną metodą wspomagającą procesy 
rozwojowe wieku dziecięcego. Bardzo ważne jest zachęcenie dziecka do ruchu, proponując mu indywidualną aktywność ruchową, nie tylko po to, aby zaoferować mu wielostronne doświadczenia, ale przede wszystkim, aby wzmocnić jego rozwój poznawczy, interpersonalny i uczuciowy. Celem niniejszego opracowania jest przedstawienie wiedzy na temat znaczenia, jakie przywiązuje się do ciała, ruchu i aktywności motorycznej w edukacji najmłodszych. Przedmiotem analiz jest problematyka edukacji przez ruch (psychomotoryki), podejmowana w badaniach naukowych w różnych krajach i ukazanie ich wartości dla praktyki edukacyjnej.

\section{ZNACZENIE PRAKTYKI RUCHOWEJ}

W prowadzonych przez nas rozważaniach, w których wiek rozwojowy, ruch, nauczanie i kształcenie łączą się ze sobą, nie można nie wspomnieć o znaczeniu zabawy (Sibilio 2005, s. 14). Dziecko nie wybiera komunikacji werbalnej, lecz komunikację za pośrednictwem ciała i działania, która przybiera formę zabawy. Przez zabawę, zjawisko spontaniczne i główne zajęcie dzieci, maluch wyraża swoją osobowość i porównuje się z innymi. Samo pochodzenie terminu „gra” ma charakter motoryczny: w pierwszych latach swojego życia małe dziecko bawi się różnymi częściami ciała, przyczyniając się do aktywnego tworzenia obrazu swojego ciała. $\mathrm{Z}$ motorycznego punktu widzenia zabawa jest wyrazem spontanicznej gimnastyki, która posiada silny potencjał edukacyjny (Ambrosini, Pellegatta 2012). Ponadto czynności ruchowe o charakterze zabawowym mają ogromną wartość psychopedagogiczną, gdyż ułatwiają nawiązywanie więzi z rówieśnikami i swobodne wyrażanie potrzeb. Zabawa łagodzi także napięcie i nudę, gdyż składa się z serii czynności sprawiających przyjemność. Dzięki zabawie komunikacja, wspomagana przez posturę, ruchy całego ciała i jego pojedyncze części, gesty, mimikę, w jej różnych wyrazach twarzy, proksemikę jest bardziej skuteczna i spontaniczna. Mowa ciała, która bez wątpienia wyraża się w ruchu, jest sposobem na uzupełnienie komunikacji werbalnej (Ambrosini, Pellegatta 2012). Innym ważnym aspektem tego zagadnienia jest możliwość obserwacji przez nauczyciela cech osobowości dziecka i próby zrozumienia różnych skłonności jego temperamentu.

Aby w pełni skorzystać z zalet praktyki ruchowej, programy wychowawczo-dydaktyczne powinny zawierać zorganizowaną i animowaną aktywność, która sprzyja zrównoważonemu i harmonijnemu rozwojowi, koniecznemu do wzmocnienia podstawowych wzorców ruchowych i schematów ciała. Schemat ciała jest całościowym obrazem, jaki każdy człowiek tworzy o sobie, sposobem w jakim nasze ciało jest widziane przez nas samych (Schilder 2010). Podstawowe wzorce ruchowe (chodzenie, bieganie, skakanie, rzucanie-chwytanie, wspinanie się itd.) 
muszą być stymulowane, utrwalane, również w celu późniejszego uczenia się funkcji motorycznych. Reasumując, dobra edukacja ruchowa stwarza warunki zrównoważonego modelu wspierania rozwoju, gdzie ruch jest postrzegany jako ważny element edukacji oraz jako środek ułatwiający kreowanie takich wartości, jak szacunek, poświęcenie, zdrowe współzawodnictwo, duch zespołu (Valentini 2009).

\section{JEAN LE BOULCH I JEGO KONCEPCJA PSYCHOMOTORYKI}

Koncepcja funkcjonalizmu uważa jednostkę za osobowość złożoną, pełniącą różne role i zarazem aktywną, a ruch i zjawiska umysłowe $\mathrm{z}$ nią połączone traktuje jako środki umożliwiające przystosowanie się do środowiska (Pesci 2012). Orientacja ta koncentruje się na rozwoju funkcjonalnym jednostki (Le Boulch 1985). Metodologia psychomotoryki odchodzi od tradycyjnego podejścia, zakładającego, że program jest narzucony uczniom przez nauczyciela na rzecz programu aktywnego, którego podstawą jest głównie zabawa, pozwalająca dzieciom na ujawnienie ich spontaniczności (Pesci 2012).

Jean Joseph Le Boulch, twórca psychomotoryki, był nauczycielem wychowania fizycznego i lekarzem, który dzięki swojemu ogromnemu doświadczeniu interdyscyplinarnemu opracował innowacyjną i edukacyjną naukę o ruchu, tworząc wizję promującą autorską metodę (Pesci 2011). W 1947 roku zdobył uprawnienia do nauczania wychowania fizycznego, po czym w 1960 roku otrzymał dyplom magisterski na kierunku lekarskim. Podczas odbywania studiów lekarskich, uczęszczał na różnego rodzaju kursy, które umożliwiły mu zdobycie certyfikatów Szkoły Wyższej na kierunkach fizyka, chemia, biologia, psychofizjologia, psychologia ogólna, psychologia genetyczna. Jego praca magisterska była prawdziwą demonstracją niedoskonałości testów sprawności fizycznej, które stosowano dotychczas dla potwierdzenia sprawności ruchowej osoby, u której - według Le Boulcha - nie można oddzielić czynników fizycznych od psychicznych. Le Boulch tym samym poszerzył rozumienie terminu „wychowanie fizyczne” o pojęcie motoryki, a w 1965 roku po raz pierwszy użył terminu „psychomotoryka”, odnoszącego się do autorskiej innowacyjnej metody wychowawczej, która wykorzystuje ludzki ruch we wszystkich jego formach, starając się wypromować podejście uwzględniające psychologiczny obraz osoby jako jednostki (Le Boulch 1985). W kolejnych latach Le Boulch rozwinął psychomotorykę funkcjonalną w odniesieniu do jednostki niezależnie od jej wieku. W 1996 roku gdy został mianowany dyrektorem naukowym „Szkoły Jean Le Boulch” we Florencji, we Włoszech, pod jego kierunkiem kształcono już zawodowych instruktorów psychomotoryki funkcjonalnej (Pesci, s. d.). 
W celu zorganizowania i stworzenia nauki o ruchu Le Boulch poświęcił swoje całe życie studiom w zakresie neuronauki, neurofizjologii i psychologii. Wierzył, że osoba jest wytworem i ogółem pewnej całości zbudowanej z elementów, które nie mogą być podzielone (Berti, Comunello 2011). Uznawał, że ludzkiego ruchu nie można rozpatrywać w odniesieniu do cząstkowych elementów, takich jak koordynacja ciała czy postawa, ale powinien być on rozpatrywany jako całościowe zdarzenie o charakterze motorycznym, zapewniające jednostce rozwój, relacje, energię i działanie oddziałujące również na innych ludzi (Zatti 2013). Le Boulch swoją działalnością spowodował, że psychomotoryka przekształciła się w dyscyplinę pedagogiczną, przy zachowaniu stałych podstaw naukowych, na jakich się zrodziła. Określił podejście pedagogiczne, które monitoruje rozwój osoby, promując edukację przez ruch, której istotą jest działanie, szacunek dla zróżnicowanych osobowości, interesów i potrzeb dzieci. Głównym celem takiej edukacji jest wspieranie wychowanków w rozwiązywaniu problemów przez stymulację rozwoju ich funkcji poznawczych, w zgodzie z ich przeżyciami uczuciowymi i emocjonalnymi. Psychomotoryka znalazła również zastosowanie jako „terapia” w pracy z osobami niedostosowanym społecznie, z niepełnosprawnością ruchową czy upośledzeniem umysłowym.

\section{PSYCHOMOTORYKA FUNKCJONALNA - PRZEGLĄD BADAŃ}

W rozważaniach na temat pedagogiki ruchu, ogromnego wkładu, jaki włożyli twórcy psychomotoryki w jej rozwój i niezwykle interesującej biografii Le Boulcha, autorki chcą podkreślić, jak ważna jest dla harmonijnego i wszechstronnego rozwoju aktywność ruchowa, podejmowana już od najmłodszych lat i promowana w środowisku szkolnym i pozaszkolnym. Innym argumentem jest zwrócenie uwagi na samą pedagogikę ruchu, której nie poświęca się jeszcze należnego zainteresowania.

Przedstawiona analiza uwzględnia niektóre $\mathrm{z}$ wielu badań, zamieszczone w elektronicznych bazach danych (Sport Discus, PsycInfo e PsycArticles) od 1990 do 2015 roku. Wybrano tu wyłącznie te doniesienia, które zostały oficjalnie opublikowane w czasopismach naukowych („Temps D’Educació”, „European Physical Education Review”, „Mackenzie De Educacao Fisica e Esporte”, „Educar 2012”, „Physical Education \& Sport Management”, „The Humanistic Psychologist”, „Polish Journal of Sport \& Tourism, „African Journal for Physical”, „Health Education”, „Recreation and Dance”), uwzględniając rzetelną ocenę specjalistów. Analizowane badania pochodzą z różnych krajów: Islandii, Hiszpanii, Finlandii, Republika Południowej Afryki, Kanady, Polski, Brazylii i Rumunii. Pod uwagę wzięto wyłącznie badania, które dotyczyły wieku rozwojowego i aktywności ru- 
chowej w środowisku szkolnym i pozaszkolnym. Prace badawcze dotyczą zabawy, aktywności sportowej, ruchu, których podmiotem były dzieci w wieku od 3 do 10 lat. Skoncentrowano się na studiach i analizie tych konkretnych badań, gdyż podkreślają one, że aktywność ruchowa pełni bardzo ważną funkcję wychowawczą, co niewątpliwie odbija się w wielu dziedzinach, nie tylko w obszarze sprawności ruchowej, od kształtowania do poprawy zdolności poznawczych, rozwoju zdolności emocjonalnych, wzmocnienia cech osobowości, takich jak wiara w siebie samego i w innych, rozwoju relacji społecznych, aż po kontrolę agresywności. Poniższa tabela porządkuje prace badawcze w sposób chronologiczny i według roku publikacji. Wykazano w niej główne cechy badań, miejsce, rok publikacji, liczba i wiek badanych, istotę projektu.

Tabela 1. Zestawienie prac badawczych opublikowanych

w latach 1990-2015 na temat edukacji przez ruch

\begin{tabular}{|c|c|c|c|c|c|c|c|}
\hline Autor & Rok & Kraj & $\begin{array}{l}\text { Liczba } \\
\text { bada- } \\
\text { nych }\end{array}$ & $\begin{array}{l}\text { Wiek } \\
\text { bada- } \\
\text { nych }\end{array}$ & Teren & $\begin{array}{l}\text { Nazwa projektu } \\
\text { badawczego }\end{array}$ & $\begin{array}{c}\text { Przedmiot } \\
\text { badań, efekty }\end{array}$ \\
\hline $\begin{array}{l}\text { Teresa Lleixà } \\
\text { Arribas }\end{array}$ & 1990 & Islandia & $\begin{array}{l}\text { Nieokre- } \\
\text { ślona }\end{array}$ & $6-10$ lat & Szkoła & $\begin{array}{l}\text { Projekt Naucza- } \\
\text { nie Globalne, } \\
\text { wzrost zorgani- } \\
\text { zowanej aktyw- } \\
\text { ności fizycznej }\end{array}$ & $\begin{array}{l}\text { Umiejętności ru- } \\
\text { chowe i poznaw- } \\
\text { cze w różnych } \\
\text { dyscyplinach }\end{array}$ \\
\hline $\begin{array}{l}\text { Juha-Pekka } \\
\text { Männistö } \\
\text { i in. }\end{array}$ & 2006 & $\begin{array}{l}\text { Finlan- } \\
\text { dia }\end{array}$ & $51 \mathrm{dzieci}$ & $5-7$ lat & Szkoła & $\begin{array}{c}\text { Podejście zorien- } \\
\text { towane na zada- } \\
\text { nie (koncentracja } \\
\text { na sprawności } \\
\text { manualnej, } \\
\text { równowadze } \\
\text { i zręczności } \\
\text { w posługiwaniu } \\
\text { się piłką }\end{array}$ & $\begin{array}{l}\text { Poprawa zdol- } \\
\text { ności rucho- } \\
\text { wych u dzieci } \\
\text { z trudnościami } \\
\text { ruchowymi }\end{array}$ \\
\hline $\begin{array}{l}\text { Joana S. } \\
\text { Magalhães } \\
\text { i in. }\end{array}$ & 2007 & Brazylia & $\begin{array}{c}\text { Nieokre- } \\
\text { ślona }\end{array}$ & $2-7$ lat & Szkoła & $\begin{array}{c}\text { Edukacja rucho- } \\
\text { wa w szkole, ruch } \\
\text { jako praktyka } \\
\text { pedagogiczna }\end{array}$ & $\begin{array}{c}\text { Planowanie } \\
\text { edukacji, rozwój } \\
\text { aspektu poznaw- } \\
\text { czego, ruchowego } \\
\text { i społecznego }\end{array}$ \\
\hline $\begin{array}{c}\text { Isabel } \\
\text { Viscarro } \\
\text { Tomàs i in. }\end{array}$ & 2011 & $\begin{array}{l}\text { Hiszpa- } \\
\text { nia }\end{array}$ & $\begin{array}{c}225 \\
\text { szkoły }\end{array}$ & 3-13 lat & Szkoła & $\begin{array}{c}\text { Analiza kształce- } \\
\text { nia zawodowego } \\
\text { nauczyciela }\end{array}$ & $\begin{array}{c}\text { Wzrost kształce- } \\
\text { nia specjalistycz- } \\
\text { nego }\end{array}$ \\
\hline
\end{tabular}




\begin{tabular}{|c|c|c|c|c|c|c|c|}
\hline Autor & Rok & Kraj & $\begin{array}{l}\text { Liczba } \\
\text { bada- } \\
\text { nych }\end{array}$ & $\begin{array}{l}\text { Wiek } \\
\text { bada- } \\
\text { nych }\end{array}$ & Teren & $\begin{array}{c}\text { Nazwa projektu } \\
\text { badawczego }\end{array}$ & $\begin{array}{c}\text { Przedmiot } \\
\text { badań, efekty }\end{array}$ \\
\hline $\begin{array}{l}\text { Neofit Ad- } \\
\text { riana i in. }\end{array}$ & 2011 & $\begin{array}{l}\text { Rumu- } \\
\text { nia }\end{array}$ & $\begin{array}{l}\text { Nieokre- } \\
\text { ślona }\end{array}$ & 9-10 lat & $\begin{array}{c}\text { Po } \\
\text { szkole }\end{array}$ & Uprawianie judo & $\begin{array}{l}\text { Wzrost zdolności } \\
\text { motorycznych, } \\
\text { wolicjonalnych } \\
\text { i intelektualnych }\end{array}$ \\
\hline $\begin{array}{l}\text { Rebecca J. } \\
\text { Lloyd }\end{array}$ & 2012 & Kanada & $\begin{array}{l}\text { Nieokre- } \\
\text { ślona }\end{array}$ & $3-8$ lat & $\begin{array}{l}\text { Szkoła } \\
\text { i po } \\
\text { szkole }\end{array}$ & $\begin{array}{c}\text { Program } \\
\text { „JungleSport”, } \\
\text { wspinaczka feno- } \\
\text { menologiczna }\end{array}$ & $\begin{array}{l}\text { Kompetencje } \\
\text { i umiejętności } \\
\text { motoryczne }\end{array}$ \\
\hline $\begin{array}{l}\text { Paulina } \\
\text { Gradus }\end{array}$ & 2014 & Polska & $\begin{array}{l}11 \text { grup } \\
\text { dzieci }\end{array}$ & 3-5 latki & Szkoła & $\begin{array}{l}\text { Aktywność ru- } \\
\text { chowa przez } 1,5 \\
\text { godziny dziennie }\end{array}$ & $\begin{array}{l}\text { Zdolność, wy- } \\
\text { trzymałość }\end{array}$ \\
\hline Soezin Krog & 2015 & $\begin{array}{l}\text { Republi- } \\
\text { ka Połu- } \\
\text { dniowej } \\
\text { Afryki }\end{array}$ & $\begin{array}{l}\text { Nieokre- } \\
\text { ślona }\end{array}$ & $0-9$ lat & $\begin{array}{l}\text { Szkoła } \\
\text { i po } \\
\text { szkole }\end{array}$ & $\begin{array}{l}\text { Ogólna aktyw- } \\
\text { ność ruchowa }\end{array}$ & $\begin{array}{l}\text { Zdolności moto- } \\
\text { ryczne i naucza- } \\
\text { nia }\end{array}$ \\
\hline
\end{tabular}

Źródło: opracowanie własne.

\section{WYNIKI BADAŃ}

Wszystkie analizowane prace badawcze miały na celu wykazanie, że ruch przynosi wiele korzyści dla globalnego rozwoju dziecka oraz jego osiągnięć. Przedstawione wskaźniki wykazują wiele korzystnych efektów, które są zróżnicowane w zależności od zastosowanej metody.

W badaniach zastosowano różne metody i narzędzia badawcze, takie jak: ankiety $z$ odpowiednimi tabelami ocen, testy ruchu typu diagnostycznego do oceny zaburzeń ruchowych (Movement-ABC), testy wydajności, zorganizowane zabawy typu fenomenologicznego jak „Jungle Sport”, studia typu diagnostycznego oparte na wywiadach i sondażach, analizę literatury. W wielu pracach była analizowana zależność pomiędzy ruchem, zdolnościami poznawczymi oraz rozwojem społecznym, dowodząc, że wzrost aktywności ruchowej oraz zabaw wpłynęły w znaczący sposób na rozwój ucznia, powodując jego większe zainteresowanie w zakresie nawiązywania relacji oraz komunikacji z rówieśnikami, jak również ekspresji własnej osobowości. Wszyscy badacze wykazali liczne korzyści wynikające z zastosowania podejścia psychokinetycznego. Efekty stymulujące zaimplementowanych badań ujawniły u dzieci i uczniów poprawę funkcjonowania poznawczego i sensorycznego, 
rozwój sprawności ruchowej, wzrost postępów w nauce szkolnej, zaobserowanie fizycznych korzyści u dzieci z widocznymi deficytami ruchowymi. Innym walorem badań był też aspekt praktyczno-diagnostyczny, jakim było ulepszenie narzędzi pedagogicznych służących do wspierania rozwoju psychofizycznego.

Podjęte badania dotyczyły wspierania rozwoju motoryki jednostki z zastosowaniem narzędzi metodycznych, takich jak zabawa, zadania i zorganizowana aktywność ruchowa. Prace Juha-Pekka Männistö, Marja Cantell, Tommi Huovinen, Libbe Kooistra i Dawne Larkin (2006) wykazały, że u dzieci z ewidentnymi trudnościami ruchowymi, poddanych specjalnemu programowi edukacji motorycznej przez okres 26 tygodni zaobserwowano trwałą poprawę zdolności ruchowych, lepsze panowanie nad kończynami i regulację napięcia mięśniowego. W badaniu wzięła udział grupa 51 dzieci w wieku od 5 do 7 lat, zostały one podzielone na 4 grupy zgodnie z problemami motorycznymi. Wyniki udowodniły skuteczne progresywne zmiany pod warunkiem, że dzieci realizują program stymulacji w sposób ciągły.

Badania Joana S. Magalhães, Marília Corrêa Kobal i Regiane Peron De Godoy (2007) wykazały, jak ważne jest prowadzenie zajęć wychowania fizycznego w przedszkolach i szkołach. Czynnikiem mającym wpływ na implementację takich zajęć jest współpraca wszystkich nauczycieli z dyrektorami szkoły i rodzicami, ze względu na to, że każdy z nich ma bezpośredni i stały kontakt z dzieckiem. Tylko dzięki wzajemnej współpracy i pracy zespołowej można przyczynić się do stworzenia programów wyższej jakości kształcenia i edukacji jednostek w przyszłości zdrowszych, bardziej przygotowanych do zadań życiowych i o wyższym poziomie samorealizacji.

Ze studiów Adriany Neofit (2011) wynika, że istnieje związek pomiędzy aktywnością ruchową a poznawczym i społecznym aspektem rozwoju. Praca pokazała, że wskazane jest, by judo uprawiać już w okresie przedszkolnym, gdyż zgodnie z głosem promotorów psychomotoryki, aktywność ta buduję integrację grupy oraz rozwija umiejętność nawiązywania i podtrzymywania relacji społecznych.

Badania Soezina Kroga (2015) pokazują zaś, że ruch ma znaczny wpływ na rozwój poznawczy i aby to wzmocnić, ruch musi stać się integralną częścią codziennego funkcjonowania jednostki. Wpływ ruchu na zdolności poznawcze powinien zatem stać się najważniejszą sprawą, szczególnie dla nauczycieli, którzy chcą pomóc uczniowi w jego ogólnym rozwoju. Nauczyciele ci powinni być świadomi korelacji pomiędzy deficytami poznawczymi a ruchowymi, powinni zatem ulepszać programy aktywności ruchowej i dbać o rozwój podstawowych zdolności motorycznych każdego dziecka.

Wszystkie podjęte badania udowodniły korzystny wpływ aktywności ruchowej na rozwój wychowanków i ich wrodzoną potrzebę swobodnego poruszania się. Niestety wykazano też, że potrzeba ta nie w pełni jest realizowana, aktywność 
fizyczna nie zawsze jest zorganizowana w sposób właściwy i uporządkowany. W żadnej z ośmiu analizowanych prac naukowych nie odnotowano negatywnych efektów związanych z realizacją programów aktywności motorycznej i ruchowej.

\section{PODSUMOWANIE}

Dzięki nauce i pracy badaczy kładzie się coraz większy nacisk na znaczenie, jakie ma edukacja skierowana na ciało i jego aktywność ruchową od dziecka, w trakcie całego okresu rozwojowego i w okresie późniejszym. Psychomotoryka zwraca uwagę na integrację ruchu $\mathrm{z}$ aspektami sensorycznymi, intelektualnymi i społecznymi. Jest wyrazem nierozerwalnego związku emocjonalności jednostki, jej sprawności ruchowej i procesów poznawczych, które rozwijają się od początku w sposób zgodny i uzupełniający. Nauka o ruchu w takim rozumieniu polega na traktowaniu ciała ludzkiego jako jedności, jako „pierwotnej całości”, a jego ruchu jako bezpośredniego punktu odniesienia, wyrazu zachowania (Le Boulch 1991). To podejście o konotacji pedagogiczno-rehabilitacyjno-terapeutycznej uznaje osobę w swojej jedności psychosomatycznej, działającej poprzez ruch w celu jej integralnego rozwoju (Le Boulch 2012). Zwraca uwagę na rozumienie uczuć i doznań, jakie przekazuje ciało, szczególnie w okresie dzieciństwa, gdyż dzieci nie zawsze potrafią wyrazić swoje potrzeby w sposób werbalny. Podejście pedagogiczne zgodne z założeniami psychomotoryki edukacyjnej pomaga jednostce w zachowaniu dobrostanu i sprzyja harmonijnemu rozwojowi.

W niniejszym opracowaniu autorki opowiadają się za pedagogiką ruchu, która powinna być realizowana od poziomu przedszkola, przez edukację dorosłych, metodami naukowymi, takimi jak metoda psychomotoryczna wdrażana w swojej rygorystycznej i precyzyjnej istocie z poszanowaniem potrzeb i emocjonalności człowieka. Opracowanie jest zarazem głosem przemawiającym za edukacją aktywną, która powierza wszystkim edukatorom, rodzicom i decydentom swoją rolę w celu promowania idei „zabawy ciała w ruchu”, zabawy pozwalającej rozwijać się dzieciom w sposób harmonijny, poznając lepiej siebie, innych oraz środowisko, w którym żyjemy. Autorki opowiadają się za pedagogiką ruchu, która obejmuje badanie ciała, ćwiczenia fizyczne nie tylko pod względem strukturalnym, anatomicznym, fizjologicznym, biochemicznym, ale także uwzględnia istotę ludzką w jej całości poznawczej, ruchowej, uczuciowej, społecznej, towarzyskiej, emocjonalnej, która nie boi się, a wręcz przeciwnie, wierzy w znaczenie, jakie mają doświadczenia praktyczne. Postulują, by zwrócić uwagę decydentów na jakość i ilość godzin wychowania fizycznego w szkole i przedszkolu, aby edukacja stała się bardziej efektywna. Opowiadają się za pedagogiką ruchu, która zajmuje się dzieciństwem 
w pełni, oddają głos kulturze ruchu, podejmują temat, który powinien być kontynuowany także na szczeblu instytucjonalnym, krajowym i światowym w przekonaniu, że przyszłe pokolenia mogą odnieść niewątpliwie korzyści w promowaniu edukacji w ruchu. W przestrzeni tej warto zgłębiać właściwą metodologię, mając na uwadze, że efekt procesu kształcenia i edukacji zależy od indywidualnych zdolności psychomotorycznych jednostek i ich potrzeb w tym zakresie.

\section{LITERATURA}

Ambrosini C., De Panfilis C., Wille A.M., 2010, La Psicomotricità. Corporeità E Azione Nella Costruzione Dell'identità. Como, Ed. Xenia.

Ambrosini C., Pellegatta, S., 2012, Il Gioco Nello Sviluppo E Nella Terapia Psicomotoria. Trento, Centro Studi Erickson.

Arribas T.L., 1990, Educació Física I Globalitat De L’ensenyament. „Temps D’educació". Barcelona, 4(2), 117-126.

Aucouturier B., Mendel G.,2003, I Bambini Si Muovono In Fretta. Bologna. Ed. Il Mulino.

Aucouturier B., 2005, Il Metodo Aucouturier. Fantasmi D’azione E Pratica Psicomotoria. Milano, Ed. Franco Angeli.

Berti E., Comunello, F., 2011, Corpo E Mente In Psicomotricità. Pensare L'azione In Educazione E Terapia. Trento: Edizioni Erickson.

Biagini A., 2008, L'educazione Psicomotoria. Bologna, Ed. Il Mulino.

Canevaro A., Rossini, S., 1983, Dalla Psicomotricità Ad Una Diversa Educazione Fisica. Torino, Omega.

Claparède E., 1952, L'educazione Funzionale. Firenze: Marzocco.

Coste J.C., 2011, La Psicomotricità. Firenze, Ed. La Nuova Italia.

De Panfilis C., Camerini G.B. ,2005, Il Significato Della Terapia Psicomotoria Nelle Disprassie In Età Evolutiva. Milano, Ed. Masson.

De Panfilis C., 2009,. Il Significato Del Corpo Nella Terapia Psicomotoria. Milano: Ed. Guerini.

Demeney G.,1921, L'école Française. Paris, L. Fournier Editeur.

Dewey J., 2004, Democrazia Ed Educazione. Firenze, Sansoni.

Di Donato M., 1984, Storia Dell'educazione Fisica E Sportiva. Indirizzi Fondamentali. Roma, Studium.

Gradus P. i in., 2014, Forms Of Physical Activity Of Biała Podlaska Preschool Children. „Polish Journal Of Sport \& Tourism”, Varsavia, 21(3), 163-173.

Koop E., 1977, The Basics Of Modern Rhythmics Gymnastics. Canada, Ed. Canadian Modern. 
Krog S., 2015, Movement Activities: A Critical Link In Developing Motor Skills And Learning In Early Childhood. African Journal For Physical, Health Education, Recreation And Dance (Ajpherd). Pretoria. 21(1:2), 426-443.

Lapierre A., 2001, Dalla Psicomotricità Relazionale All'analisi Corporea Della Relazione. Roma, Armando Editore.

Lapierre A., Aucouturier B., 2007, La Simbologia Del Movimento Edipsicologiche. Milano, Ed. Franco Angeli.

Le Boulch J., 1953, L'éducation Physique Fonctionnelle À L'école Primaire, Publication Du C.R.E.P.S. De Dinard.

Le Boulch J., 1960, Les Facteurs De La Valeur Motrice, Thèse 100, Faculté De Médecine Et De Pharmacie De Rennes.

Le Boulch J., 1961, L'avvenire Di Una Educazione Fisica Scientifica. Roma, Società Stampa Sportiva.

Le Boulch J., 1966, L'éducation Par Le Mouvement: La Psycho-Cinétique À L'âge Scolaire. Nogent-Le-Rotrou, Les Editions Esf.

Le Boulch J., 1977, Face Au Sport - De L'éducation Physique En France Depuis 1945 À La Psychocinétique - Etude Critique Et Perspectives. Nogent-Le-Rotrou, Les Editions Esf.

Le Boulch J., 1981,. Lo Sviluppo Psicomotorio Dalla Nascita A Sei Anni. Milano: Armando Editore.

Le Boulch J., 1985, Principi E Metodologia Dell'educazione E Della Rieducazione Psicomotoria. Roma, Ed. Marrapese.

Le Boulch J., 1989, L'educazione Psicomotoria Nella Scuola Elementare. Milano, Edizioni Unicopli.

Le Boulch J., 1990, Sport Educativo. Psicocinetica E Apprendimento Motorio. Roma, Armando Editore.

Le Boulch J., 1991, Verso Una Scienza Del Movimento Umano. Roma, Armando Editore.

Le Boulch J., 1998, Le Corps À L'école Au Xxi Siècle. Paris, Éditions Puf.

Le Boulch J., 1999, Educare Con Il Movimento. Milano, Armando Editore.

Le Boulch J., 2000, Educazione Del Corpo Nella Scuola Del Domani. Roma, Edizioni Scientifiche Magi.

Le Boulch J., 2006, Movimento E Sviluppo Della Persona. Roma, Ed. Musicalificio Grande Blu.

Le Boulch J., 2009, Lo Sport Nella Scuola. Psicocinetica E Apprendimento Motorio. Roma, Armando Editore.

Lloyd R.J., 2012, Moving Learn And Learning To Move: A Phenomenological Exploration OfChildren's Climbing With An Interdisciplinary Movement Consciousness. „The Humanistic Psychologist”, United Kingdom. 40(1), 23-37. 
Magalhães J.S., 2007, Educação Fisica Na Educação Infantil: Uma Parceria Necessária. „Revista Mackenzie De Educação Fisica E Esporte”. Brasil. 6(3), 43-52.

Männistö J.-P. i in., 2006,. A School-Based Movement Programme For Children With Motor Learning Difficult. „European Physical Education Review”, London, 12(3), 273-285.

Neofit A., i in., 2011, Psycho Motility And Its Development In Preschool Age Judo, The Annals Of "Dunarea De Jos" University Of Galati, Fascicle Xv: Physical Education \& Sport Management, Galati. 1, 135-139.

Pesci G., (S. D.). Biografia Autorizzata. Disponibile Su: Http://Psicomotricitafunzionale.It/Biografia/

Pesci G., 1991, Il Corpo Nella Relazione. Roma, Armando Editore.

Pesci G., 2011, La Psicomotricità Funzionale. Scienza E Metodologia. Roma, Armando Editore

Pesci G., 2012,. Teoria E Pratica Della Psicomotricità Funzionale. A Scuola Con Jean Le Boulch. Roma, Armando Editore.

Pesci G., Zoccolini L., 2014, Linguaggio Verbale E Tonematico Nel Principio Sistemico. Educazione Dell'espressione Elocutoria In: Psicomotricità Funzionale. Firenze, Edizioni Scientifiche Isfar.

Sibilio M., 2005, Lo Sport Come Percorso Educativo. Attività Sportive E Forme Intellettive. Napoli, Alfredo Guida Editore.

Schilder P., 2010, L’immagine Di Sé E Schema Corporeo. Milano, Ed. Franco Angeli. Tomàs I.V. i in., 2011, Perfil Y Formación De Los Profesionales Que Realizan La Práctica. Educar 2012, Barcelona. 48(2), 321-344.

Valentini C., 2009, Imparare Ad Imparare, [pozyskano z: http://Www.Pavonerisorse.It/Meta/Gioco/Gioco2.Htm>, 2009].

Wille A., Ambrosini C., 2005, Manuale Di Terapia Psicomotoria Dell’età Evolutiva. Napoli, Ed. Cuzzoli.

Zanibelli G., 2013, Elementi Fondamentali Di Psicomotricità. Napoli, Ed. Piccin. Zatti A., 2013, Il Sentimento Motorio. Psico-Socio-Ecologia Dell'educazione Psicomotoria. Milano, Franco Angeli.

\section{EDUCATION THROUGH MOVEMENT IN RESEARCH PRACTICE}

\footnotetext{
Abstract: Several multidisciplinary and international studies have shown that learning processes can be constructed by means of embodiment, through education in or of the body and contribute to the person-child's cognitive, social, emotional and relational development, considered in its uniqueness, as well as to their health. The educator and doctor Jean Le Boulch is
} 
thought to be the greatest exponent in the science of movement, with his Psychomotor learning theory. No intellectual progress can be accomplished without the help of the body, and motor skills require the use of psychological factors, therefore, to a Human Being, given that it is made up of a set of many units, it must therefore be used globally. Through studies included in this research it was further stressed that psychomotor offers important advantages for the integral development of a child. The article is a review of scientific research on educational psychomotor and its numerous benefits for the child's integral development. It emphasized that harmony between the mind and the body promotes positive growth processes of the individual.

Keywords: psychomotor, motor activities, developmental age, pedagogy, psychophysics Unit 